\title{
Quantification of Tourism Sector Parameters Related to Competitiveness of Countries According to Macroeconomic Indicators
}

\section{- Beata Gavurova, Andrej Privara, Jana Janikova, Viliam Kovac}

\begin{abstract}
The paper investigates the relations of the macroeconomic indicators related to the competitiveness of the tourism sector among the explored countries. The tourism sector plays an important role with the purpose of contributing to the economy of each country and, thus, its competitiveness among the other countries. The fundamental aim of the paper is to investigate the relations between the macroeconomic indicators related to tourism and their influence on the economy of the countries. The data set comprises the eight macroeconomic indicators, of which the four ones are related to the gross domestic product, the two ones to employment, the penultimate one to investment, and the last one to expenditure. The observed period covers the years 1995 to 2019. The Euclidean distance is employed to evaluate the similarity of the countries and the cluster analysis to group them successively. There are several patterns visible in the analysis outcome. Firstly, the countries that behave differently for both groups of the indicators with Mexico at the top position. Secondly, the countries with considerable change throughout the observed period where Greece stands at the most extreme position for the gross domestic product indicators and Hungary in the case of the other economic indicators. Thirdly, Chile remains at the evenest position throughout the whole explored period for the first group of the indicators and the United States for the second group of the indicators. Finally, Australia has almost the same development for both groups at the evenest tendency.
\end{abstract}

Keywords: gross domestic product, competitiveness, employment, investment, expenditure, macroeconomic indicator, cluster analysis

JEL Classification: E20, Z31, Z32

Received: March, 2021

\section{INTRODUCTION}

The international reports declare the persistent trends in increasing tourism competitiveness (World Economic Forum, 2019). Significant support plays an important role in this process by improving transport infrastructure in the countries, enabling the interconnection of the economy sectors supporting the development of tourism, and by the other factors. Enhancement 
of transport infrastructure is reflected in an increase of the capacity of the routes and the number of transport companies offering their services in individual countries (Skare et al., 2020a). Travelling has also become cheaper and more affordable over recent time and, thus, increasingly competitive (Poliak et al., 2021). The international openness of economies, which is threatened by many negative globalization processes, bears great importance, too (Skare et al., 2020b). A positive point is represented by the fact that international openness increasingly affects the lower-income economies. It results in the overall competitiveness of the tourism sector from a global perspective. In recent years, research on the development of the tourism sector and its competitiveness in relation to the preservation of cultural and natural wealth comes to the foreground (Streimikiene \& Ahmed, 2021). These processes are reflected in an increase in the number of environmental agreements between the countries supporting the sustainability of tourism on a national and global scale (Caplanova \& Willett, 2019). Both the professional and scientific communities call for the creation of active mechanisms to ensure better funding for the sector and more efficient marketing campaigns, as well as more favorable perception of the tourism sector and its benefits for the economy of the countries (Androniceanu, 2017). In order to develop the active policies and the related regulatory and stabilization mechanisms enabling progress in the development of this sector, it is necessary to examine the sector through a causal interconnection with the important metrics expressing quantification of economic and social impacts on the society (Svagzdiene et al., 2020; Szostek et al., 2020). These analytical processes allow the researchers to understand in a better way not only the position of the countries in assessment of the tourism sector contribution but also to identify the factors causing the differences between the countries and to examine the important causal relations, including fiscal policy (Androniceanu et al., 2019; Šimelytè et al. 2021). This also makes it possible to evaluate the competitive potential of the region or the country and to create a quality forecasting platform for the further development of the sector in the context of globalization as well as national influences (Androniceanu, 2019; Xu et al., 2020). These consistent facts create a motivation to carry out the research, whose primary goal is to reveal relations of the macroeconomic indicators related to the tourism sector among the explored countries. This study offers a novel view on the relations between the analyzed countries linked to the selected macroeconomic indicators as a key factor of competitiveness of the involved countries through its outcome and discussion.

\section{LITERATURE REVIEW}

Many international research studies have examined the relations between the tourism sector and the macroeconomic indicators in recent years. The research scope of these studies is widespread and determined by the target focus of the research team as well as the usability of the outputs for other research areas and policymaking (Tvaronaviciene \& Burinskas, 2020). There is a special benefit of the results of these studies in clarifying the significance of the examined variables along with revealing new assumptions of the actions related to the factors and together with creating an active discussion platform. They can also support the development of national and international benchmarking indicators useful for comparative studies and new methodologies (Tvaronavičienè \& Jurgelevičius, 2020). Narayan et al. (2021) examine the role of tourism in explaining the current account balance of the Republic of Indonesia. In this investigation, the 
authors supply the model of the determinants of the current account by tourism and the expected and unexpected tourist shocks. The authors point out that these positive shocks caused by tourism have improved the current account balance of the country in the period from the year 2010 to the year 2017. The expected shocks from tourism worsened the current account which was already in deficit, but they improved it in a case of surplus. The unexpected shocks related to tourism improved the current account balance regardless of whether the account was in deficit or surplus. Aratuo \& Etienne (2019) focus on analyzing the six industries related to tourism in the United States of America during the period from the year 1998 to the year 2017. Their analysis shows that, apart from the accommodation, hospitality and beverage sectors, there is no long-term relationship between the other tourism sectors and economic growth. The authors declare that investments in tourism can be successful in the long run, even in times of economic stagnation. In the short term, the tourism industry can benefit from the country's economic growth. At the end of the study, the implications are given to support investment and marketing processes related to tourism with an emphasis on the catering, shopping and leisure sectors. Malik \& Latif (2021) pay attention to examining the new determinants of the foreign direct foreign investment of the People's Republic of China. Outgoing Chinese foreign direct investment attracts Chinese foreign tourism. The analysis outcome demonstrates that if the host countries were glad to attract foreign direct investment, they would enhance and adopt policies to support the tourism sector. The inflow of foreign direct investment is also affected by the degree of trade openness. This fact is examined in a sample of the 36 developing economies Liargovas \& Skandalis (2012). The authors apply the regression analysis in a panel form, which declared the positive impact of trade openness on the inflow of foreign direct investment into the developing economies. These results are confirmed by the other research studies (Chakrabarti, 2001; Biglaiser \& DeRouen, 2006), but there are also the studies that declare the opposite effect, that is, a negative relationship between the inflow of foreign direct investment and the degree of trade openness (Zhang, 2015). An explicit definition of the factors influencing the foreign direct investment is tricky as several research studies declare the influence of the factors such as exchange rate, the openness of the economy, political stability or political risks, wage, trade, investment costs, human capital, taxes, inflation, budget deficits, domestic investment, foreign debt, and so forth (Trevino \& Mixon, 2004; Bloningen, 2005; Omisakin et al., 2009). Special importance is borne by innovative development and the degree of usability of innovation in this process. It is reflected not only in the indicators of regional development but also creates a platform to eliminate the disparities between the territories or the countries (Belas et al., 2020a, b; Gavurova et al., 2020). On the other hand, such measures have a positive effect on overall well-being (Orviska et al., 2014). The study by Hyun et al. (2006) draws attention to the need to examine the causal relationship between economic growth and tourism expansion. Based on the results of the analysis, the authors confirm the long-term equilibrium relationship as well as the two-way causal relationship between these two factors. It means tourism and economic development are mutually supporting in the Republic of China. The study provides the implications and recommendations for the policymaking processes. Santana-Gallego et al. (2010) scrutinize the impact of the exchange rate volatility on tourism development. The authors apply the technique of panel data analysis. They perform the relevance analysis demonstrating that less flexible exchange rates support tourism. Eugenio-Martin et al. (2008) add the factor of 
economic development to the confrontation of tourism development. They consider it the driving force of tourism at a given time. A change in the decisions of the tourists is also important according to the analysis outcome. In the countries with a high level of gross domestic product, the differences in economic development are less pronounced, but in the developing countries, they are significant. Many research studies focus on the importance of tourism as a major source of income linked to the aggregate macroeconomic indicators (Muriithi et al., 2019; Skare \& Kukurin, 2020). Bazargani et al. (2021) focus on the categories of competitiveness and performance of tourism. The authors appeal to the lack of studies examining the competitiveness of tourism with relation to its performance. The study is clearly dominated by the global perspective of the mentioned connection. The competitiveness of tourism generates its contribution to the gross domestic product in all the regions and the income groups worldwide. The authors identify the infrastructure, political stability, a favorable environment, the natural and cultural conditions that also affect the performance of tourism as the important determinants of the competitiveness of tourism. The authors formulate significant implications for the policymaking process, too. A similar business environment analysis can also be understood from a social and cultural view. Ghosh \& Mitra (2021) also examine the impact of tourism on income inequality in a group of countries categorized according to their level of economic development. The authors build the three clusters based on a triplet of the variables - the gross domestic product per capita, the volume of international trade, and the inflow of foreign direct investment. Income inequality is measured through the Gini coefficient. This study also demonstrates that tourism revenues have different effects on the observed countries. The inequality index of the most developed countries was not affected by the tourism revenues. The studies show the different degrees of the impact of the investigated variables, even when the countries surveyed have the same or similar economy and socioeconomic positions (Aratuo \& Etienne, 2019; Belas et al., 2020b). This brings to the foreground the question of a deeper examination of the causal relations between the determinants of tourism development through a performance of the multidimensional studies as well as an assessment of the outputs from the evaluating and monitoring processes (Svagzdiene et al., 2020; Tarí et al., 2020). Also, the presentation of tourism plays an important role in the field of its management (Jupowicz-Ginalska \& Paták, 2018), which can be more effective in case of high levels of institutional trust (Caplanova et al., 2021). The presented research studies and the results coming from their analyses represent a valuable theoretical platform necessary to clarify the importance of the explored variables along with an identification of the potential points for subsequent research based on a deeper examination of the causal relations and revealing new determinants of tourism development.

\section{AIM, DATA AND METHODOLOGY}

The main aim of the paper is to investigate the relations between the macroeconomic indicators related to tourism and their influence on the economy of the countries. The data comes from the online database of the World Travel \& Tourism Council. There are eight indicators included in the explored data set. In all the cases, the shared version of the indicators is applied as a relative expression is much more interpretable than absolute value. The comprised parameters are as follows: business tourism spending in gross domestic product share, direct gross domestic 
product contribution in gross domestic product share, leisure tourism spending in gross domestic product share, total gross domestic product contribution in gross domestic product share, direct contribution to employment in employment share, the total contribution to employment in employment share, capital investment in investment share, individual government expenditures in total government expenditure share. For the analytical process, the two main groups of the indicators are constructed.

On the one hand, the first one is devoted to the indicators related to the gross domestic product, and on the other hand, the second one is devoted to the indicators related to employment, investment and expenditure named as the other macroeconomic indicators throughout the further text of the paper. All the indicators are expressed in a percentage way. The online links to the data set are not included in the text of the paper, because at the time of completion of the article, the database website shut down for an unknown reason. Therefore, the direct links cannot be provided, and it is useless to mention the previously working links as it is not known anything about future access to the database. The data set covers the time span from the year 1995 to the year 2019. Hence, the observed data is as latest as it is possible because the data for the year 2020 is not made public until the present time. The choice of the countries almost meets the member list of the Organization for Economic Cooperation and Development. The remaining countries are not involved in the analysis because of a lack of data. There is to note that all the countries are mentioned in the text by their colloquial names. The list of the countries is ordered in alphabetical order according to these names. The abbreviations come from the official source of the International Organization for Standardization 3166-1 standard that is part of the International Organization for Standardization 3166 norm (International Organization for Standardization, 2013). The principle analytical methodology is based on cluster analysis. The similarity of the countries is computed through the Euclidean distance. It is visualized by the heat maps demonstrating the similarity of each pair of the involved countries. The darker the color cell is displayed; the higher dissimilarity is between the countries of that pair. Successively, the numerical quantification of the mean distance representing the mean similarity of each country is pictured by means of the table. This perspective offers a good view of the separate countries based on an individual aspect. Finally, the dendrograms illustrate the division of the countries. Determination of the number of clusters is carried out according to the KrzanowskiLai criterion (Krzanowski \& Lai, 1988). The input data for its computation is the situation at the beginning of the explored period in the year 1995.

\section{RESULTS AND DISCUSSION}

The analysis outcome is supported by visualization of similarity through the heat maps and the constructed clusters through the dendrograms. At first, the relations between the observed countries are identified by means of their mutual similarity. Figure 1 demonstrates the similarity of the examined countries according to the gross domestic product indicators at the beginning of the explored period in the year 1995. The explored countries are as follows: the Commonwealth of Australia - AU, the Republic of Austria - AT, the Kingdom of Belgium - BE, Canada - CA, the Czech Republic - CZ, the Kingdom of Denmark - DK, the Republic of Estonia - EE, the Republic of Finland - FI, the French Republic - FR, the Federal Republic of Germany - DE, the 
Hellenic Republic - GR, Hungary - HU, the Republic of Chile - CL, Iceland - IS, Ireland - IE, the State of Israel - IS, the Italian Republic - IT, Japan - JP, the Grand Duchy of Luxembourg LU, the United Mexican States - MX, the Netherlands - NL, New Zealand - NZ, the Kingdom of Norway - NO, the Republic of Poland - PL, the Portuguese Republic - PT, the Slovak Republic - SK, the Republic of Slovenia - SI, the Republic of Korea - RK, the Kingdom of Spain - ES, the Kingdom of Sweden - SE, the Swiss Confederation - CH, the Republic of Turkey - TR, the United Kingdom of Great Britain and Northern Ireland - GB, the United States of America - US.

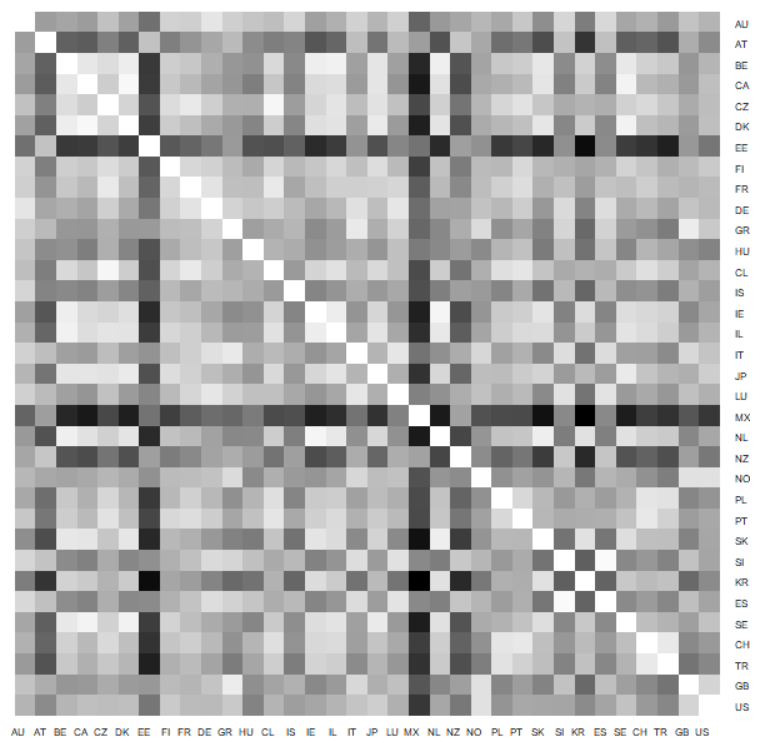

Fig. 1 - The gross domestic product indicators similarity at the beginning of the explored period. Source: own research

At the beginning of the explored period in the year 1995, the most extreme position in the case of the gross domestic product indicators is held by Mexico, Estonia, New Zealand, and Austria. From a numerical point of view, the highest mean dissimilarity at a level of 4.9115 is kept by Mexico that is followed by Estonia with a value of 4.4585, quite surprisingly. On the other hand, there are plenty of similar countries - the six ones ranging from a level of 1.8331 representing the Czech Republic up to a threshold of 2 followed by the remaining countries with very short gaps. Figure 2 visualizes the similarity of the examined countries according to the gross domestic product indicators at the end of the explored period in the year 2019. 


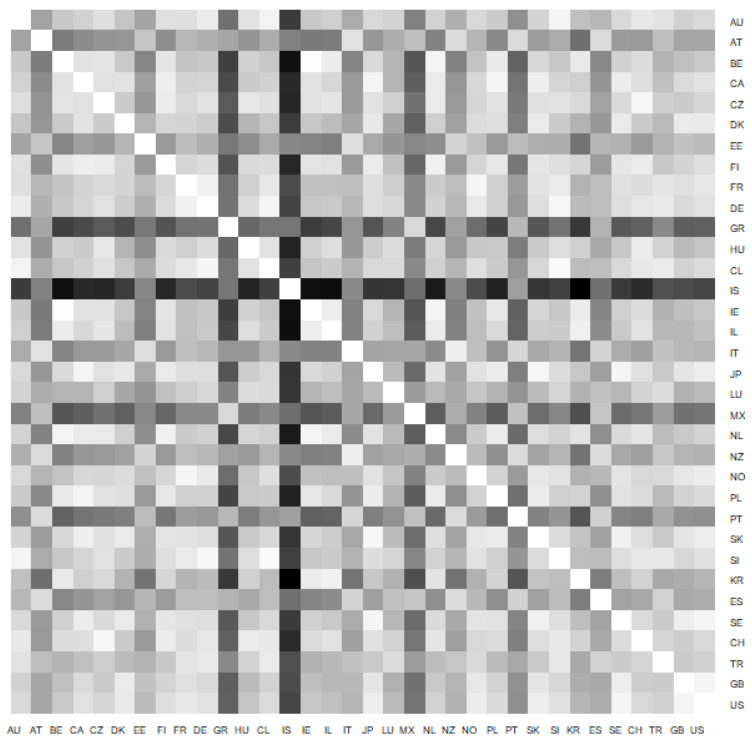

Fig. 2 - The gross domestic product indicators similarity at the end of the explored period. Source: own research

The end of the examined period looks very different from its initial point. Germany and Iceland stay at the most different positions, followed by Mexico and Portugal with several countries behind them. Numerical expression puts on the highest position Hungary with a mean distance from the rest of the countries at a value of 5.3791. It is followed by Iceland with a mutual mean distance of 4.7263. On the opposite side, the lowest value of 1.7231 is kept by the United Kingdom. Figure 3 imagines the similarity of the examined countries according to the gross domestic product indicators throughout the whole explored period.

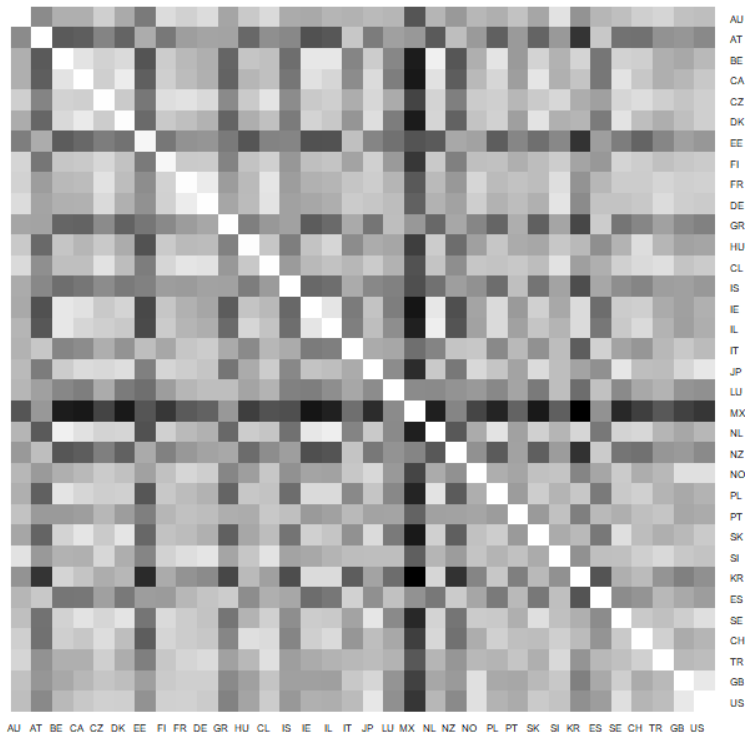

Fig. 3 - The gross domestic product indicators similarity throughout the explored period. Source: own research 
A situation assigned to the whole examined period is partially different. Although Mexico stands at the most different place with a 4.8031, there are several countries very close to each other from the second place starting with Estonia at a level of 3.5815 and followed by New Zealand with a value of 3.2320, Austria with a value of 3.2184, Greece with a value of 3.1120, and Iceland with a value of 3.0714. On the other hand, the most similar country is represented by Chile at a level of 1.7429 and very closely, the Czech Republic at a level of 1.7521 with France at a level of 1.7537. Figure 4 demonstrates the similarity of the examined countries according to the other macroeconomic indicators at the beginning of the explored period in the year 1995.

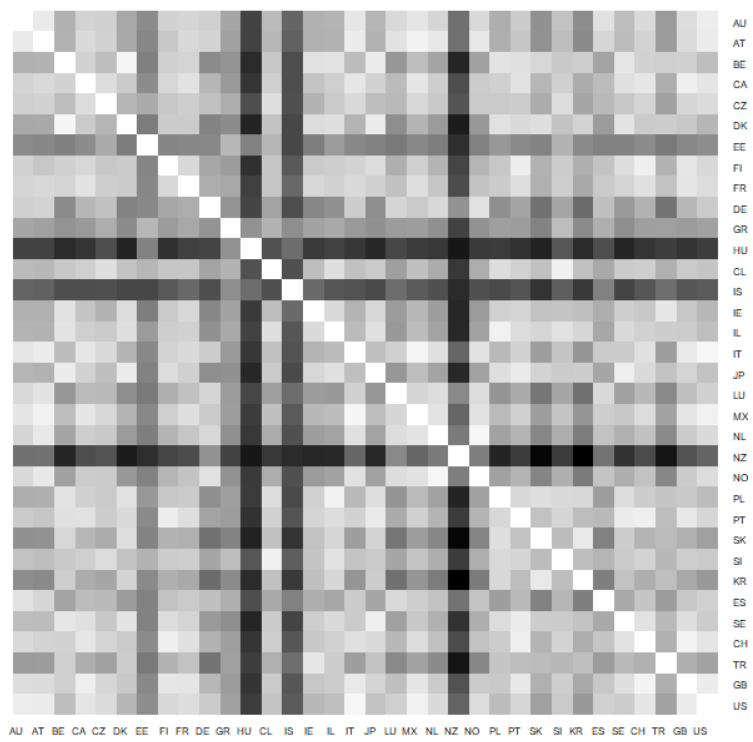

Fig. 4 - The other macroeconomic indicators similarity at the beginning of the explored period. Source: own research

In the case of the other macroeconomic indicators, a situation is absolutely different from the gross domestic product indicators. The highest position is kept by Hungary at a level of 5.3791, and it is followed by New Zealand with a value of 5.2059 and Iceland with a value of 4.7263 . Contrariwise, the United Kingdom keeps the lowest position at a level of 1.7231. Closely, it is followed by Canada with a value of 1.7646 , the United States with a value of 1.7679, and France with a value of 1.7756 . Several more countries succeed very nearly.

Figure 5 visualizes the similarity of the examined countries according to the other macroeconomic indicators at the end of the explored period in the year 2019. 


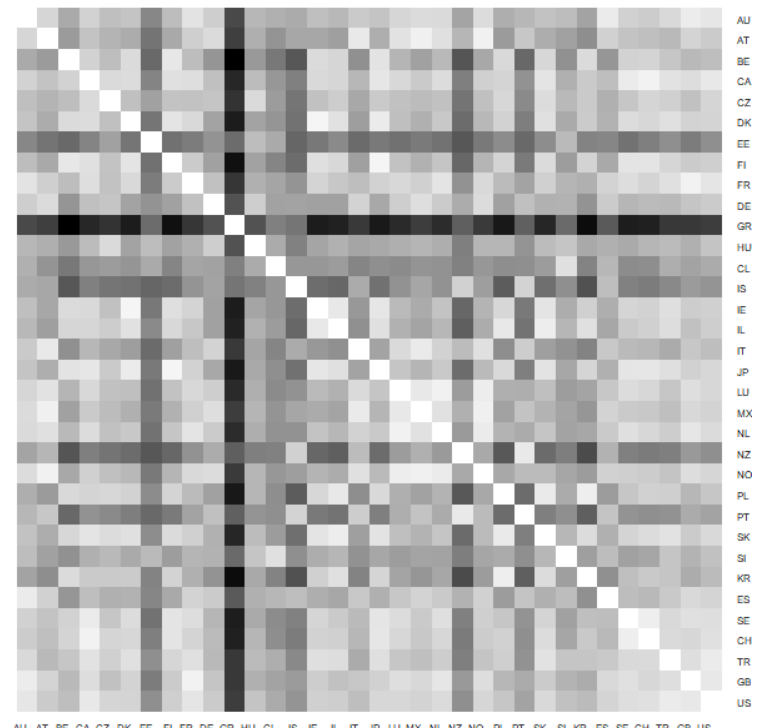

Fig. 5 - The other macroeconomic indicators similarity at the end of the explored period. Source: own research

No country is repeated from the beginning of the explored period, and only Iceland appears at the top of dissimilarity from the ranking assigned to the gross domestic product indicators. The most similar country from the rest of the whole set is represented by the United States at a level of 1.7295. A handful of the countries follow this top position - Canada with a value of 1.8079, the United Kingdom with a value of 1.8261 , Turkey with a value of 1.8620 , France with a value of 1.8632 , and Australia with a value of 1.8780 .

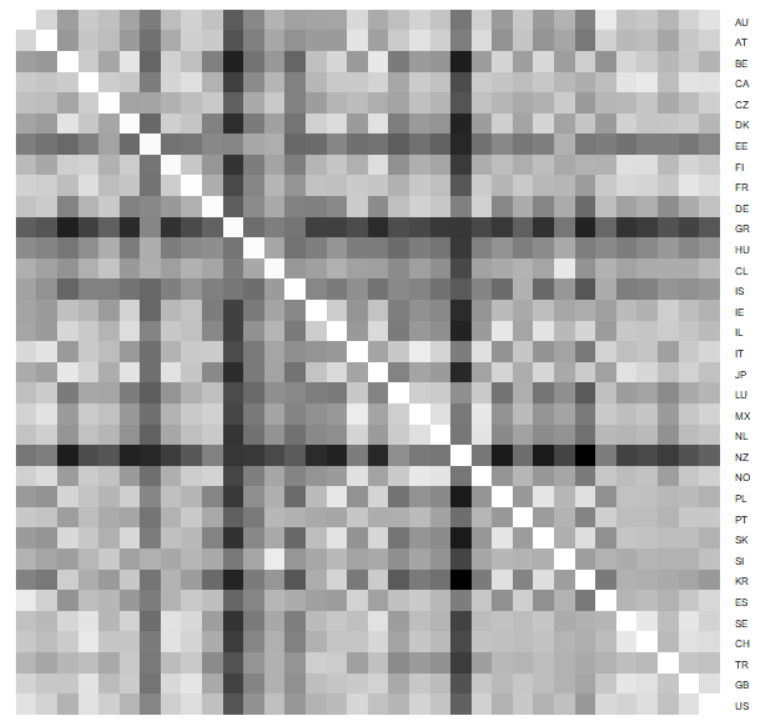

Fig. 6 - The other macroeconomic indicators similarity throughout the explored period. Source: own research 
The whole explored period from a perspective of the other macroeconomic indicators is characterized by the two top dissimilar countries - Greece standing at a level of 4.5774 and New Zealand at a level of 4.5530. Estonia follows these countries with a value of 3.4289. On the opposite side, the United States defend its position at a level of 1.7280 from both ends of the period. Hence, it is apparent this position is assigned to this country deservedly. The repeating countries remain at the bottom of the ranking - Canada with a value of 1.7686 , the United Kingdom with a value of 1.7863 , and France with a value of 1.8092 . The mean similarity values for the particular countries are illustrated in the following table, demonstrating the six values representing the various views - the beginning and the end of the explored period with its mean value for both view of the gross domestic product indicators and the other macroeconomic indicators.

Tab. 1 - The similarity of the individual countries according to the gross domestic product indicators and the other macroeconomic indicators at the beginning of the explored period, at the end of the explored period, and throughout the explored period. Source: own research

\begin{tabular}{|l|l|l|l|l|l|l|}
\hline Country & \multicolumn{3}{|l|}{ Gross domestic product indicators } & \multicolumn{3}{l|}{ Other macroeconomic indicators } \\
\hline & Beginning & End & Period & Beginning & End & Period \\
\hline AU & 2.1328 & 1.8083 & 1.9423 & 1.9313 & 1.8780 & 1.9314 \\
\hline AT & 3.3481 & 2.8345 & 3.2184 & 1.9220 & 2.1847 & 2.0725 \\
\hline BE & 2.1154 & 2.2548 & 2.1784 & 2.0419 & 2.5943 & 2.3178 \\
\hline CA & 2.3460 & 1.9362 & 2.1416 & 1.7646 & 1.8079 & 1.7686 \\
\hline CZ & 1.8331 & 1.8386 & 1.7521 & 1.9144 & 2.1666 & 2.0471 \\
\hline DK & 2.2280 & 2.1274 & 2.1841 & 2.2053 & 2.1450 & 2.2575 \\
\hline EE & 4.4585 & 2.8056 & 3.5815 & 3.3743 & 3.8440 & 3.4289 \\
\hline FI & 1.9513 & 1.8515 & 1.8513 & 1.9154 & 2.2328 & 2.0563 \\
\hline FR & 1.8401 & 1.6920 & 1.7537 & 1.7756 & 1.8632 & 1.8092 \\
\hline DE & 1.9330 & 1.6568 & 1.7926 & 2.6167 & 2.2524 & 2.4192 \\
\hline GR & 2.3149 & 4.5138 & 3.1120 & 2.8264 & 6.0299 & 4.5774 \\
\hline HU & 2.6992 & 2.0794 & 2.2793 & 5.3791 & 2.5241 & 3.1891 \\
\hline CL & 1.8852 & 1.7167 & 1.7429 & 2.0181 & 3.1102 & 2.2402 \\
\hline IS & 2.8791 & 5.7875 & 3.0714 & 4.7263 & 3.5715 & 3.1948 \\
\hline IE & 2.2833 & 2.2911 & 2.3421 & 2.1664 & 2.2040 & 2.4231 \\
\hline IL & 2.0137 & 2.3059 & 2.2366 & 1.9550 & 2.2620 & 2.1396 \\
\hline IT & 2.1356 & 2.6205 & 2.3515 & 1.8350 & 2.4831 & 2.0589 \\
\hline JP & 1.9794 & 1.7902 & 1.9633 & 2.0368 & 2.0622 & 2.1122 \\
\hline LU & 2.1466 & 2.2619 & 2.6838 & 2.4159 & 2.0214 & 2.6300 \\
\hline MX & 4.9115 & 3.9384 & 4.8031 & 1.8180 & 2.0678 & 2.0774 \\
\hline NL & 2.3627 & 2.0527 & 2.1360 & 2.2577 & 1.9458 & 2.3675 \\
\hline NZ & 3.5716 & 2.6354 & 3.2320 & 5.2059 & 3.6300 & 4.5530 \\
\hline NO & 2.4009 & 1.7424 & 2.0654 & 2.2492 & 1.9925 & 2.0876 \\
\hline & & & & & & \\
\hline
\end{tabular}




\begin{tabular}{|l|l|l|l|l|l|l|}
\hline PL & 2.3457 & 2.0529 & 2.2263 & 2.0461 & 2.4099 & 2.3083 \\
\hline PT & 2.0078 & 3.3788 & 2.2732 & 1.7886 & 3.1127 & 2.1611 \\
\hline SK & 2.5719 & 1.7975 & 2.2489 & 2.6558 & 2.0251 & 2.3058 \\
\hline SI & 2.3929 & 1.6799 & 1.8390 & 1.9207 & 2.6131 & 2.2079 \\
\hline KR & 3.0639 & 2.6610 & 2.9731 & 2.7710 & 2.7082 & 2.8042 \\
\hline ES & 2.3579 & 2.5920 & 2.5652 & 2.2711 & 2.1598 & 2.0697 \\
\hline SE & 2.2343 & 1.8035 & 1.9214 & 1.9587 & 1.9665 & 1.9113 \\
\hline CH & 2.2396 & 1.7809 & 1.9655 & 1.7476 & 1.9355 & 1.8474 \\
\hline TR & 2.6365 & 1.8769 & 1.9606 & 2.6004 & 1.8620 & 2.2095 \\
\hline GB & 2.4849 & 1.9300 & 2.0708 & 1.7231 & 1.8261 & 1.7863 \\
\hline US & 2.3804 & 1.7728 & 1.9825 & 1.7679 & 1.7295 & 1.7280 \\
\hline
\end{tabular}

There is to note that the above-placed table offers the mean distance values in order to compare the observed countries individually. Many countries behave unexpectedly. This could be a warning point that something influences the explored parameters in a way that is not standard. Perhaps, a further investigation should be employed aimed at the particular countries, but not only with the explanation of the ending points of the period and thus, but the shorter time interval would also be more suitable to be implemented. Such an approach would make clear some of the observed shifts.

On the other hand, there are also the countries with an apparent trend of their movement. For instance, an upward trend in the case of the gross domestic product indicators is seen for Portugal and Greece. Altogether, there are many more countries with the downward shift, although this change is not so clear as in the opposite case. For instance, Norway, Slovakia, Switzerland, Turkey, the United Kingdom, and the United States perform in such sinking trend. A key for the other macroeconomic indicators looks a little bit differently. A division of the upward or downward movement would halve approximately the whole set. Some of the extremely localized countries, like Iceland, for instance, possess the mean value lower than the values assigned to both ends of the explored period. It presumes high fluctuations of the numbers throughout the whole explored period. Figure 7 illustrates the division of the countries into separate clusters at the beginning of the explored period in the year 1995.

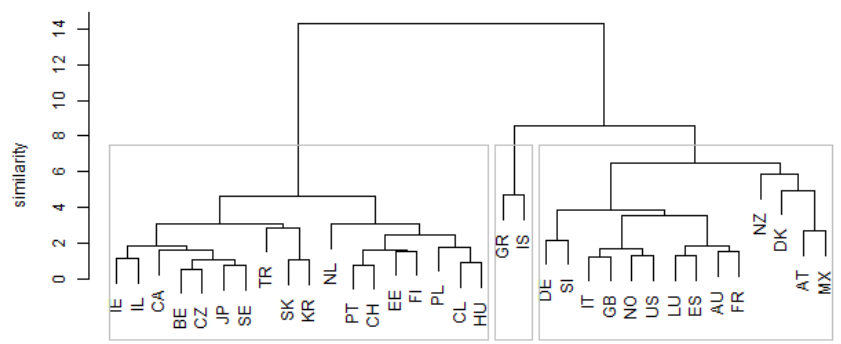

Fig. 7 - The dendrogram illustrating the cluster division at the beginning of the explored period. Source: own research 
The cluster division is done according to all the observed indicators together. The division of the countries into the individual clusters is very loosely based on the similarity among the involved countries. The most identifiable point is created by the outlying countries - Greece, Iceland, New Zealand, and Denmark. The remaining participating countries are considerably similar in order to create a determining rule. Figure 8 demonstrates the division of the countries into separate clusters at the end of the explored period in the year 2019.

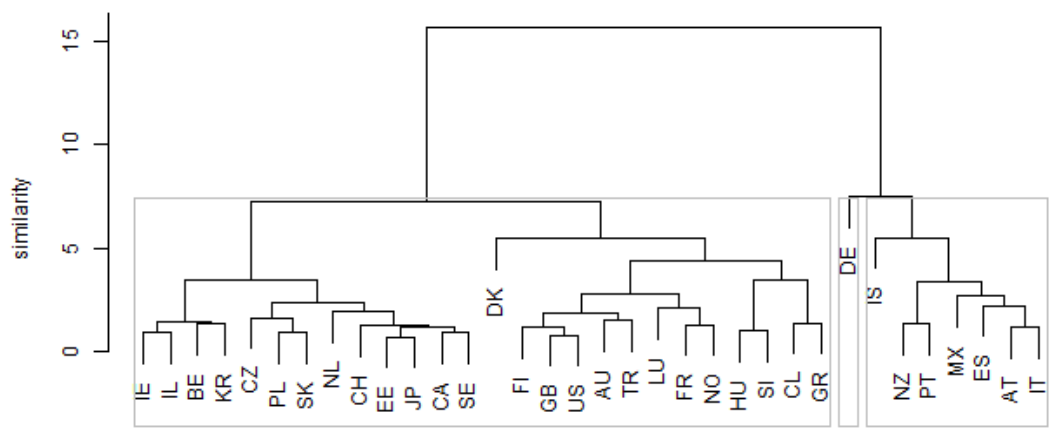

Fig. 8 - The dendrogram illustrating the cluster division at the end of the explored period. Source: own elaboration by the authors

Apart from the beginning of the explored period, there are higher similarities among the countries generally. Denmark and Iceland remain at the extreme positions, whilst Germany has shifted to the most extreme itself. Although there is a considerable movement among the clusters during the explored period, Mexico stays very near Austria, and Spain is quite similar to this pair. Another pair, but localized on the opposite side of the dendrogram, which remains shoulder to shoulder, is created by Ireland and Israel. There is to note that Denmark has shifted from the relatively upper dissimilar position from the third cluster to the center of the first cluster, where it stands alone just right below the most upper-division within this cluster. Many countries have left their position from the beginning of the observed period. This fact confirms high fluctuations of similarity among the countries and makes the outcome of the analysis more complicated from an angle of its interpretation. It would not be determining, but it also worsens the potential further analytical steps. Hence, it is a crucial point how to assess the possible changes in the explored parameters. Aratuo \& Etienne (2019) evaluate the gross domestic product as statistically significant in their regression model in the field of tourism-led economic growth.

On the other hand, Bazargani \& Kilic (2021) consider the gross domestic product as statistically insignificant in their regression models in the standard panel regression analysis, whilst the logarithmic version of the indicator is significant for all the countries but the upper-middleincome countries. Bloningen (2005) confirms the gross domestic product and investment as important for the tourism sector. The gross domestic product can also be understood from a view of its growth rate as inspected by Narayan et al. (2021) through the regression analysis. Also, its lagged values are considered, and they are found statistically significant along with the 
current version. Foreign direct investment is statistically significant in the case of explanation of the Gini coefficient in the regression model by Ghosh \& Mitra (2021). Outbound tourism is expressed as an influencing factor of outward foreign direct investment by Malik \& Latif (2021). Tvaronaviciene \& Burinskas (2020) consider the unemployment rate to be one of the factors impelling the tourism sector, as confirmed by the four types of regression models. To summarize it all, the gross domestic product is the most frequently applied indicator generally as it is expected. Hence, the first group of the indicators is based just right on this parameter analysis, and thus, higher importance is devoted to this parameter than the others.

\section{CONCLUSION}

Tourism is the largest and most dynamically developing service sector. Its progress is influenced by the globalization trends, the process of demographic aging, the economic parameters, the geographical conditions of the country, the consumers' behavior, but also by the global crises and risks. It is evolving thanks to new destinations, markets, activities in the services sector, but it is also significantly affected by technological development. It plays an important economic role in sustainable regional development, where it is an effective tool for the development of the lagged territories. Monitoring and quantification of the economic and social parameters of the tourism sector are problematic, especially from the procedural and methodological point of view. Tourism is characterized by a lack of aggregate as well as comparative data along with their systemic interconnectedness. This also makes the creation of the analytical studies necessary for the conception of the national and international policies more complicated, as well as the creation of the national and international benchmarking indicators. These aspects raise the need for the construction of the concepts and the multidimensional analyses that would examine the causal relationships between the individual indicators of the tourism sector with its sustainable development too and hence, to quantify the sensitivity of the individual dimensions to the external changes, the global crises, the structural changes in economies, and so forth. The carried-out analysis touches on a few issues of the tourism sector. The computed similarity of the explored countries brings several interesting findings. Firstly, there are the countries that behave differently from the perspective of the groups of the observed macroeconomic indicators. For instance, Mexico is an excellent example of such behavior. It plays an outlying role in the case of the gross domestic product indicators, but for the other macroeconomic indicators, it lies in an average position. Austria behaves similarly, too, but it does not keep such a strong position according to the gross domestic product indicators. Secondly, there are the countries with considerable change throughout the observed period. Namely, in the case of the gross domestic product indicators, Estonia looks more average at the end of the period, unlike the beginning and vice versa, Greece is more outlying at the end of the period.

On the other hand, the other macroeconomic indicators demonstrated by Hungary, New Zealand, and Iceland are more average at the end of the period. Thirdly, another pattern is seen for Chile, Finland, France, and Spain that keep a very even position from gross domestic product indicators perspective. Conversely, Sweden and the United States play such a role in the other macroeconomic indicators. Altogether, Australia behaves very similarly for both groups of the examined indicators. Stimulating productivity growth through the development of the tourism 
sector is often considered an important economic development strategy for the most developed countries. Due to the growing importance of the tourism sector to the country's economy, attention is paid to the causal relationship between tourism expenditure and the country's productivity. It is also important because understanding the causal relationships between them is essential in designing and implementation of tourism policies.

\section{Acknowledgments}

This work is supported by the Scientific Grant Agency of the Ministry of Education, Science, Research, and Sport of the Slovak Republic and the Slovak Academy Sciences as part of the research project VEGA No. 1/0797/20.

\section{References}

1. Androniceanu, A. (2017). The three-dimensional approach of Total Quality Management, an essential strategic option for business excellence. Amfiteatru Economic, 19 (44), 61-78.

2. Androniceanu, A. (2019). Collaborative digital economy, main attributes, and challenges. In: Peters M. (eds) Encyclopedia of Educational Philosophy and Theory. Singapore: Springer Nature Singapore Pte Ltd. https://doi.org/10.1007/978-981-287-532-7_699-1

3. Androniceanu, A., Gherghina, R. \& Ciobanasu, M. (2019). The interdependence between fiscal public policies and tax evasion. Administratie si Management Public, 32, 32-41. https://doi.org/10.24818/amp/2019.32-03

4. Aratuo, D. N., \& Etienne, X. L. (2019). Industry-level analysis of tourism-economic growth in the United States. Tourism Management, 70, 333-340. https://doi.org/10.1016/j.tourman.2018.09.004

5. Bazargani, R. H. Z., \& Kilic, H. (2021). Tourism competitiveness and tourism sector performance: Empirical insights from new data. Journal of Hospitality and Tourism Management, 46, 73-82. https://doi.org/10.1016/j.jhtm.2020.11.011

6. Belas, J., Amoah, J., Petrakova, Z., Kljuchnikava, Y., \& Bilan, Y. (2020a). Selected Factors of SMEs Management in the Service Sector. Journal of Tourism and Services, 21 (11), 129-146. https://doi.org/10.29036/jots.v11i21.215

7. Belas, J., Gavurova, B., Cepel, M., \& Kubak, M. (2020b). Evaluation of the economic potential of business environment development by comparing sector differences: the perspective of SMEs in the Czech Republic and Slovakia. Oeconomia Copernicana, 11 (1), 135-159. https://doi.org/10.24136/oc.2020.006

8. Biglaiser, G., \& DeRouen, K. (2006). Economic reforms and inflows of foreign direct investment in Latin America. Latin American Research Review, 41 (1), 51-75. Available online: https://www.jstor.org/stable/3662784

9. Bloningen, B. A. (2005). A review of the empirical literature on FDI determinants. National Bureau of Economic Research Working Papers, 11299. https://doi.org/10.3386/w11299

10. Caplanova, A., \& Willett, K. (2019). Emission Discharge Permit Trading and Persistent Air Pollutants (A Common Pool Market Application with Health Risk Specifications). International Advances in Economic Research, Springer. International Atlantic Economic Society, 25 (1), 19-38. https://doi.org/10.1007/s11294-019-09720-z 
11. Caplanova, A., Sivak, R. \& Szakadatova, E. (2021). Institutional Trust and Compliance with Measures to Fight COVID-19. International Advances in Economic Research, 27, 47-60. https://doi.org/10.1007/s11294-021-09818-3

12. Chakrabarti, A. (2001). The determinants of foreign direct investment: Sensitivity analyses of cross-country regressions. Kyklos, 54 (1), 89-112. https://doi.org/10.1111/1467-6435.00142

13. Eugenio-Martin, J. L., Martin-Morales, N., \& Sinclair, M. T. (2008). The Role of Economic Development in Tourism Demand. Tourism Economics, 14 (4), 673-690. https://doi.org/10.5367/000000008786440111

14. Gavurova, B., Belas, J., Bilan, Y., \& Horak, J. (2020). Study of legislative and administrative obstacles to SMEs business in the Czech Republic and Slovakia. Oeconomia Copernicana, 11 (4), 689-719. https://doi.org/10.24136/oc.2020.028

15. Ghosh, S., \& Mitra, S. K. (2021). Tourism and inequality: A relook on the Kuznets curve. Tourism Management, 83, 104255. https://doi.org/10.1016/j.tourman.2020.104255

16. Hyun, J. K., Ming-Hsiang, Ch., \& SooCheong, S. J. (2006). Tourism expansion and economic development: The case of Taiwan. Tourism Management, 27 (5), 925-933. https://doi.org/10.1016/j.tourman.2005.05.011

17. International Organization for Standardization. (2013). International Organization for Standardization 3166 - International Standard for country codes and codes for their subdivisions.

18. Jupowicz-Ginalska, A., \& Paták, M. (2018). Management of Travel and Transport Destinations' Presentation in the Travel Specialized Print Media. International Journal of Entrepreneurial Knowledge, 6 (2), 81-99. https://doi.org/10.2478/IJEK-2018-0016

19. Krzanowski, W. J., \& Lai, Y. T. (1988). A Criterion for Determining the Number of Groups in a Data Set Using Sum-of-Squares Clustering. Biometrics, 44 (1), 23-34. https://doi.org/10.2307/2531893

20. Liargovas, P. G., \& Skandalis, K. S. (2012). Foreign Direct Investment and Trade Openness: The Case of Developing Economies. Social Indicators Research, 106, 323-331. https://doi.org/10.1007/s11205-011-9806-9

21. Malik, M. Y., \& Latif, K. (2021). Impact of outbound tourism on outward FDI. Annals of Tourism Research, in press, 103140. https://doi.org/10.1016/j.annals.2021.103140

22. Muriithi, R. W., Kyalo, T., \& Kinyanjui, J. (2019). Assessment of the relationship between entrepreneurial orientation, organisational culture adaptability and performance of Christian faith-based hotels in Kenya. International Journal of Entrepreneurial Knowledge, 7 (1), 31-45. https://doi.org/10.2478/ijek-2019-0003

23. Narayan, S., Narayan, P. K., \& Tobing, L. (2021). Has tourism influenced Indonesia's current account? Economic Analysis and Policy, 69, 225-237. https://doi.org/10.1016/j.eap.2020.12.009

24. Omisakin, O., Adeniyi, O., \& Omojolaibi, A. (2009). Foreign Direct Investment, Trade Openness and Growth in Nigeria. Journal of Economics Theory, 3, 13-18. https://doi.org/jeth.2009.13.18

25. Orviska, M., Čaplánová, A., \& Hudson, J. (2014). The Impact of Democracy on Well-being. Social Indicators Research, 115, 493-508. https://doi.org/10.1007/s11205-012-9997-8 
26. Poliak, M., Svabova, L., Konecny, V., Zhuravleva, N. A., \& Culik, K. (2021). New paradigms of quantification of economic efficiency in the transport sector. Oeconomia Copernicana, 12 (1), 193-212. https://doi.org/10.24136/oc.2021.008

27. Santana-Gallego, M., Ledesma-Rodrígues, F., \& Pérez-Rodríguez, J. (2010). Exchange rate regimes and tourism. Tourism Economics, 16 (1), 25-43. https://10.5367/000000010790872015

28. Šimelytė, A., Tvaronavičienė, M., Holmen, R. B., Burinskas, A., \& Razminienė, K. (2021). Knowledge and Technology Transfer as Driving Force for Social Innovations. Polish Journal of Management Studies, 23 (2), 512-536. https://doi.org/10.17512/pjms.2021.23.2.31.

29. Skare, M., \& Kukurin, Z. (2020). Measuring the Effects of VAT Changes on the Tourism Industry in the Case of Croatia. Transformations in Business \& Economics, 19 (2), 271-282.

30. Skare, M., Franc-Dąbrowska, J., \& Cvek, D. (2020b). Cointegration analysis and VECM of FDI, employment, export and GDP in Croatia (2002-2017) with particular reference to the global crisis and poor macroeconomic governance. Equilibrium. Quarterly Journal of Economics and Economic Policy, 15 (4), 761-783. https://doi.org/10.24136/eq.2020.033

31. Skare, M., Tomic, D., \& Kristek, I. (2020a). Terms of Trade Impact on International Trade: A Panel Cointegration Analysis. Transformations in Business \& Economics, 19 (3(51)).

32. Streimikiene, D., \& Ahmed, R. R. (2021). The integration of corporate social responsibility and marketing concepts as a business strategy: evidence from SEM-based multivariate and Toda-Yamamoto causality models. Oeconomia Copernicana, 12 (1), 125-157. https://doi.org/10.24136/oc.2021.006

33. Svagzdiene, B., Perkumiene, D., Grigiene, J., \& Bilan, S. (2020). Characteristics of Service Quality Evaluation in Rural Tourism Sector: Case of the Baltic States (Lithuania, Latvia, Poland). Transformations in Business \& Economics, 19 (2), 495-510.

34. Szostek, D., Balcerzak, A., P., \& Rogalska, E. (2020). The relationship between personality, organizational and interpersonal counterproductive work challenges in industry 4.0. Acta Montanistica Slovaca, 25 (4), 577-592. https://doi.org/10.46544/ams.v25i4.11

35. Tarí, J. J., Pereira-Moliner, J., Molina-Azorín, J. F., \& López-Gamero, M. D. (2020). A Taxonomy of Quality Standard Adoption: Its Relationship with Quality Management and Performance in Tourism Organizations in Spain. Journal of Tourism and Services, 21 (11), 22-37. https://doi.org/10.29036/jots.v11i21.151

36. Trevino, L. J., \& Mixon, F. G., Jr. (2004). Strategic factors affecting foreign direct investment decisions by multi-national enterprises in Latin America. Journal of World Business, 39 (3), 233-243. https://doi.org/10.1016/j.jwb.2004.04.003

37. Tvaronaviciene, M., \& Burinskas, A. (2020). Industry 4.0 Significance to competition and the EU competition policy. Economics and Sociology, 13 (3), 244-258.

https://doi.org/10.14254/2071-789X.2020/13-3/15

38. Tvaronavičienè, M., \& Jurgelevičius, A. (2020). The New Concept of Human Capital and its Impact Economy in European Countries. Polish Journal of Management Studies, 22 (2), 561-575. https://doi.org/10.17512/pjms.2020.22.2.37

39. World Economic Forum (2019). The Travel \& Tourism Competitiveness Report 2019 - Travel and Tourism at a Tipping Point. World Economic Forum. Available online: http://www3. weforum.org/docs/WEF_TTCR_2019.pdf 
40. Xu, F., Ma, L., Liunata, L., Najaf, I., \& Streimikiene, D. (2020). Does Social Responsibility Increase the Corporate Value of China's Coal Enterprises? The Mediating Effect of Capital Enrichment Based on the Generalized Moment Estimation. Acta Montanistica Slovaca, 25 (3), 274-288. https://doi.org/10.46544/ams.v25i3.2

41. Zhang, C., Yueteng, Z., \& Zhe, L. (2015). Trade openness, financial openness, and financial development in China. Journal of International Money and Finance, 59, 287-309.

https://doi.org/10.1016/j.jimonfin.2015.07.010

\section{Contact information}

prof. Ing. Beata Gavurova, PhD., $M B A$

Technical University of Košice

Faculty of Mining, Ecology, Process Control and Geotechnologies

Letná 9, 04200 Košice

Slovakia

E-mail:beata.gavurova@tuke.sk

ORCID: 0000-0002-0606-879X

Ing. Andrej Privara, PhD.

University of Economics in Bratislava, Faculty of National Economy

Dolnozemská cesta 1, 85235 Bratislava

Slovakia

E-mail:andrej.privara@euba.sk.

ORCID: 0000-0001-9737-7338

Ing. Jana Janikova, $M B A$

Faculty of Operation and Economics of Transport and Communications

University of Žilina

Univerzitná 8215/1

01026 Žilina

Slovakia

E-mail:janikova@mail.vstecb.cz.

ORCID: 0000-0002-2746-7896

Ing. Viliam Kovac, PhD.

Košice Self-governing Region

Námestie Maratónu mieru 1

04266 Košice

Slovakia

E-mail:viliam.kovac@vucke.sk.

ORCID: 0000-0002-5265-9005 